\title{
Preliminary Study of Slaughter Value and Meat Characteristics of 18 Months Ostrich Reared in Hungary
}

\author{
Lili Dóra Brassó ${ }^{1,2, *}$, Vanessza Szabó ${ }^{1}$, István Komlósi ${ }^{1}$, Tünde Pusztahelyi ${ }^{3}$ and Zsófia Várszegi ${ }^{1}$ \\ 1 Department of Animal Husbandry, Faculty of Agricultural and Food Sciences and Environmental \\ Management, University of Debrecen, 4032 Debrecen, Hungary; kylee6992@gmail.com (V.S.); \\ komlosi@agr.unideb.hu (I.K.); varszegi@agr.unideb.hu (Z.V.) \\ 2 Doctoral School of Animal Science, University of Debrecen, 4032 Debrecen, Hungary \\ 3 Central Laboratory of Agricultural and Food Products, 4032 Debrecen, Hungary; pusztahelyi@agr.unideb.hu \\ * Correspondence: brasso.dora@agr.unideb.hu
}

check for updates

Citation: Brassó, L.D.; Szabó, V.; Komlósi, I.; Pusztahelyi, T.; Várszegi, Z. Preliminary Study of Slaughter Value and Meat Characteristics of 18 Months Ostrich Reared in Hungary. Agriculture 2021, 11, 885. https:// doi.org/10.3390/agriculture11090885

Academic Editor: Vincenzo Tufarelli

Received: 11 August 2021

Accepted: 13 September 2021

Published: 15 September 2021

Publisher's Note: MDPI stays neutral with regard to jurisdictional claims in published maps and institutional affiliations.

Copyright: (c) 2021 by the authors. Licensee MDPI, Basel, Switzerland. This article is an open access article distributed under the terms and conditions of the Creative Commons Attribution (CC BY) license (https:// creativecommons.org/licenses/by/ $4.0 /)$.

\begin{abstract}
The study aimed to evaluate the slaughter value and meat characteristics of ten ostrich females reared and slaughtered at the age of 18 months in Hungary. The ratio of selected body parts, the main organs and the lean meat parts were examined. The nutritive composition, the colour, the technological and organoleptic characteristics of five valuable meat parts (outside strip-M. flexor cruris lateralis, oyster-M. iliofemoralis externus, tip-M. femorotibialis medius, outside leg-M. gastrocnemius pars externa, medal-M. ambiens) and the amino acid, fatty acid and mineral composition of outside strip (M. flexor cruris lateralis) were also evaluated. The ratio of body parts and the main organs as the percentage of live weight, and the lean meat part as the percentage of carcass weight showed $16.74 \pm 0.01 \%, 6.16 \pm 0.01 \%$ and $57.29 \pm 0.59 \%$, respectively. The dry matter content of the examined valuable meat parts ranged between $24.89 \pm 0.08$ and $26.23 \pm 0.13 \%$, the protein ratio took on values between $18.40 \pm 0.09$ and $20.62 \pm 0.16 \%$, the fat content showed values between $2.36 \pm 0.07$ and $4.50 \pm 1.09 \%$ and the hydroxyproline content ranged between $0.01 \pm 0.001$ and $0.08 \pm 0.001 \%$. The amino acid content of the outside strip showed a range between 0.15 and $3.33 \%$. The ratio of SFA, MUFA and PUFA was $35.10 \pm 0.53,37.37 \pm 1.52$ and $27.54 \pm 1.01$. The $\mathrm{n}-6 / \mathrm{n}-3$ ratio showed $3.91 \pm 0.43$ and the SFA/UFA ratio was $0.54 \pm 0.02$. Among the examined minerals, the content of $\mathrm{Ca}, \mathrm{K}, \mathrm{Mg}, \mathrm{Na}$ and $\mathrm{P}$ was the highest in the meat. In the case of the colour, regarding $L^{*}$ value, we could reveal no significant difference between the examined meat parts. For $a^{*}$ and $b^{*}$ values, the outside leg had the lowest data of all. We could not reveal a significant difference between the $\mathrm{pH}$ values of the meat parts. Regarding technological parameters, meat differed only in thawing loss. The significantly lowest thawing loss could be detected in the outside $\operatorname{leg}(2.72 \pm 0.01 \%)$ and in the medal $(2.32 \pm 0.01 \%)$. The results of the organoleptic evaluation showed that the outside strip and the tip had the best flavour and tenderness. In comparison with the younger birds (10-14 months of age) in the literature, the 18-month-old ostriches in our study showed similar or slightly lower slaughter weight, skin weight and head ratio, greater liver weight, lighter meat, lower protein and higher fat content, higher essential amino acid and lower non-essential amino acid content and higher SFA content in some cases. However, data on nutrition and population size were not always available. In comparison with other ratites (emu and rhea), ostrich meat has lower dry matter and protein, but higher fat, SFA, MUFA and PUFA content and lower n-6/n-3 ratio.
\end{abstract}

Keywords: ostrich; meat production; meat nutritive composition; amino acids; fatty acids; minerals; technological and organoleptic characteristics

\section{Introduction}

Alternative food sources that support healthy human nutrition are in heavy demand. Ostrich meat, as lean meat with low intramuscular fat $(0.5 \%)$ and cholesterol content [1], is suitable for this purpose. Due to its status as a gourmet product and its high price, ostrich 
meat is usually purchased by the wealthy. Compared to beef and poultry, ostrich meat has a favourable fatty acid profile and low fat content [2], and it is characterised by a beef-like taste and tenderness [3]. According to Balog and Almeida [4], consumers prefer ostrich to beef because of its low intramuscular fat content. Although the prime product of the ostrich industry is meat, skin, oil and feathers are also processed. Ostrich meat production ranges from 12 to 15 thousand tonnes, $60 \%$ of which comes from South Africa. The major producers are South Africa, the USA, Australia, Spain, Poland and the Middle East. The ostrich meat industry produces mostly fresh meat, including steak and hamburger meat, as well as dry goods. [5].

Hungary exports live ostriches and ostrich meat (approximately three thousand slaughtered birds a year) to France. Ostrich meat is also purchased by local consumers and restaurants in the capital. The outside strip, the oyster, the tip, the outside leg, the medal and the fan are considered to be the most valuable cuts of the lean meat parts. In Hungary, the outside strip and the fan are sold vacuum packed as raw or smoked meat or sliced prosciutto crudo. The oyster is used for preparing pate, while the tip and the outside leg are used for sausages and salami.

As with all ratites, the largest amount of meat can be found on the thigh, while the smallest is on the breast, wings and back. Ostriches reach the optimal slaughter age at 12-14 months [6], although birds of the Zimbabwean blue neck genotype provide a satisfying amount of meat at the age of 10-12 months [7]. The Struthio camelus species can be characterized with a $57-58 \%$ slaughter yield and $62.5 \%$ lean meat $[8,9]$. For slaughter animals, maintainer feed is usually provided from 10 months of age until slaughter with $8-10 \mathrm{MJ} / \mathrm{kg}$ energy, $12-14 \%$ protein, $2.5 \%$ fat, $0.9-1.4 \% \mathrm{Ca}$ and $0.6 \mathrm{~g} / \mathrm{kg}$ lysine content [10]. Due to its high iron content, ostrich meat has dark red pigmentation but the iron concentration may vary among meat parts [11]. There has been no scientific result on raw meat smell, but packaging technology and storage time influence this parameter [12]. The smell is determined by water-soluble molecules, whereas flavour is mainly influenced by fat-soluble compounds [13]. For consumers, the other significant meat characteristic is tenderness. This parameter is affected by the cooking technology employed and also by the cooking temperature [14]. When compared to beef, ostrich meat is stiffer and drier because it has lower connective tissue and collagen content. Juiciness and tenderness are closely linked and consumers consider juicier meat to be more tender, too [13]. Taylor et al. [14] also report a relation between low fat content, juiciness and texture. Under 15 months of age, ostrich meat is more tender [15]. Technological characteristics of meat, such as thawing, dripping and cooking loss are also relevant from the market point of view. These characteristics, including texture and tenderness, are influenced by the water-holding capacity of the meat [16]. Cooking loss increases with longer storage time [17]. Higher $\mathrm{pH}$ value improves water-holding capacity, thus it decreases drip loss [18]. The mean $\mathrm{pH}$ value of ostrich meat is 7.2, but it increases after $24 \mathrm{~h}$ and facilitates meat processing [19]. Ostrich meat has a regular $(<5.8)$ to high $(>6.2) 24 \mathrm{~h}$ postmortem $\mathrm{pH}$ [1].

In this preliminary study, we aimed to assess the slaughter value and meat characteristics of ostriches reared in Hungary. The slaughtered animals were six months older than the optimal slaughter age (12 months) since the COVID-19 pandemic substantially decreased the capacity of the HORECA (hotel/restaurant/catering) sector. Zimbabwean ostriches are known to have constant weight over the age of one year [20]. As regards the age of the birds, we wanted to assess the slaughter value and meat characteristics of older animals and to compare them with those of the ostriches that were slaughtered at the optimal age (10-14 months). Although extensive literature is available on this topic, none of the studies included a wide range of parameters examined similar to ours. In Hungary, no research findings have been published on this species so far. The present article is the first one to evaluate the whole spectrum of meat production characteristics of ostriches. In this respect, our findings can be considered to be gap filling. However, regarding the small number of the evaluated birds, the present research can offer only preliminary results. 


\section{Materials and Methods}

\subsection{The Animals and the Slaughter Process}

The ten female ostriches used in our examination came from a farm in Jászberény in the Central Hungary region with a continental climate. Polipor-98 Ltd. is the largest company producing slaughter birds for export. Semi-intensive, grain-based fattening technology was applied with coarse feed supplementation (alfalfa). The birds received starter feed $(0.02-0.12 \mathrm{~kg} /$ day $/$ bird $)$ from week 0 to 8 , then starter + grower $(0.55-0.65 \mathrm{~kg} /$ day $/ \mathrm{bird})$ from week 9 to 11 . After that, grower $(0.75-1.4 \mathrm{~kg} /$ day $/ \mathrm{bird})$ feed was provided for them from week 12 to 24 , then maintainer $(1.5 \mathrm{~kg} /$ day/bird) from week 25 until slaughter. The starter feed was composed of maize, wheat, non-GMO soybean meal, alfalfa pellets, full-fat soy, sunflower meal, sugar beet pellets and vegetable oil. The starter feed had $12 \mathrm{MJ} / \mathrm{kg}$ energy, $21.00 \%$ raw protein, $4.00 \%$ fat, $6.70 \%$ fibre, $7.5 \%$ ash and $1.15 \%$ lysine content. The grower feed included maize, wheat, alfalfa meal, sunflower meal, soybean meal, FF soybean, dried beet pulp and non-GMO soybean meal. The grower feed contained $10 \mathrm{MJ} / \mathrm{kg}$ energy, $18.00 \%$ protein, $3.70 \%$ fat, $8.20 \%$ fibre, $7.52 \%$ ash and $0.95 \%$ lysine. The maintainer feed comprised maize, alfalfa pellets, wheat, sunflower meal, full-fat soybean, beet pellets and vegetable oil. The maintainer had $8 \mathrm{MJ} / \mathrm{kg}$ energy, $16.20 \%$ protein, $3.80 \%$ fat, $9.40 \%$ fibre, $6.92 \%$ ash and $0.80 \%$ lysine content. The feed was purchased from Agrofeed Ltd.

Chicks were nursed on a $2 \mathrm{~m} \times 0.8 \mathrm{~m} \times 1 \mathrm{~m}$ sized battery until the age of two weeks with a total of twenty birds of mixed gender. After that, they were moved to deep litter until three months of age with $5 \mathrm{~m}^{2}$ /bird stocking density and mixed gender. From the age of three months until slaughter, the animals were kept in a $300 \mathrm{~m}^{2}$ pen with a stocking density of $10 \mathrm{~m}^{2} /$ bird and mixed gender. The fattening process was accomplished on the same farm; the pens were placed next to each other, so the environmental conditions were considered equal for each animal. The keeping conditions met the requirements of the Model Code of Practice for the Welfare of Animals [21].

After the birds were stunned and bled on the farm, they were processed three hours later in a slaughterhouse in Tokaj. The birds were 18 months of age with a $100.9 \pm 4.48 \mathrm{~kg}$ live and $51.75 \pm 2.18 \mathrm{~kg}$ carcass weight. In the slaughterhouse, we measured the weight of skin with feathers, the head, the feet, the diaphragm and the internal organs (heart, lung, liver and gizzard) with a two-decimal digital balance. The carcass was cooled to $4{ }^{\circ} \mathrm{C}$ and divided into meat parts $24 \mathrm{~h}$ after slaughter. The weight of all meat parts located on the left leg and the back was measured.

\section{2. $\mathrm{pH}$ and Colour Determinations}

We recorded the colour and the $\mathrm{pH}$ value of five valuable meat parts (outside strip, oyster, tip, outside leg and medal) all used in further evaluations. The $\mathrm{pH}$ value was measured $24 \mathrm{~h}$ after slaughter by Testo AG Germany $205 \mathrm{pH}$ value gauge. The $\mathrm{pH}$ value gauge was immersed in buffer solution before measurement. For meat colour $\left(\mathrm{L}^{*}, \mathrm{a}^{*}, \mathrm{~b}^{*}\right)$ examination, the Konica Minolta CR-410 Chroma Meter was applied $24 \mathrm{~h}$ after slaughter with a 21 min blooming time. The Chroma Meter was calibrated with the use of a white calibration plate before the analysis, setting the $\mathrm{Y}, \mathrm{x}$ and $\mathrm{y}$ illuminant coordinates $(\mathrm{Y}=93.7$, $\mathrm{x}=0.3144, \mathrm{y}=0.3204)$. Regarding meat colour, $\mathrm{L}^{*}, \mathrm{a}^{*}$ and $\mathrm{b}^{*}$ values represent a colour space defined by CIE. $\mathrm{L}^{*}$ value expresses lightness, $\mathrm{a}^{*}$ and $\mathrm{b}^{*}$ refer to the greenness and redness, blueness and yellowness of meat [22].

\subsection{Kjeldahl-Method for $N$ Analysis}

From the prepared (ground) samples, $1 \mathrm{~g}$ was measured on nitrogen-free paper and folded into it. The digestion of these samples was initiated with two $3.5 \mathrm{~g}$ Se-Kjeldahl tablets (VWR International) and $14 \mathrm{~mL}$ conc. $\mathrm{H}_{2} \mathrm{SO}_{4}$. The digestion was performed at $420{ }^{\circ} \mathrm{C}$. After cooling, the samples were distilled in UDK 149 distiller (VELP Scientifica Srl, Usmate, Italy) and ammonium was released by $33(\mathrm{~m} / \mathrm{m}) \% \mathrm{NaOH}$ addition and loaded 
into $4 \%(w / w) \%$ boric acid solution. The $\mathrm{N}$ was determined by titrimetric analysis with $0.2 \mathrm{~N} \mathrm{H}_{2} \mathrm{SO}_{4}$ in TITROLINE 5000 automatic titrator (VELP Scientifica Srl, Usmate, Italy).

\subsection{Total Fat Content Assessment}

The measurement was performed according to the MSZ ISO 1443:2002 standard. The ground samples (3-5 g) were measured and treated with $50 \mathrm{~mL}$ conc. $\mathrm{HCl}$ for $1 \mathrm{~h}$; then $150 \mathrm{~mL}$ hot water was added to it. The solution was filtered through a filter paper and washed with hot water until the $\mathrm{pH}$ was neutral. The filtrate was dried at $103 \pm 2{ }^{\circ} \mathrm{C}$ for $1 \mathrm{~h}$. The filter paper with the filtrate was inserted into TECATOR Soxtec fat extractor and extracted with petrol ether $\left(40-60^{\circ} \mathrm{C}\right)$. The extracted fat was dried and measured. The fat was further analysed for fatty acid composition.

\subsection{The Examination of Fatty Acid Composition}

The fatty acid composition was determined as methylated fatty acid composition based on the ISO 12966-2:217 standard sample preparation method. The fat (Section 2.4) was dissolved in $6 \mathrm{~mL}$ hexane and $12 \mathrm{~mL} \mathrm{NaOH}: \mathrm{MeOH}$ and was treated at $80^{\circ} \mathrm{C}$ for 10 min for saponification. Afterwards, the solution was diluted with water and the nonsaponified compound was extracted with hexane. The remaining solution was acidified with $0.5 \mathrm{~mL} 6 \mathrm{M} \mathrm{H}_{2} \mathrm{SO}_{4}$ and with hexane again; then the fatty acids were extracted and separated. After the addition of $2 \mathrm{~mL} \mathrm{BF3:MeOH}$, it was heated at $80^{\circ} \mathrm{C}$ for $30 \mathrm{~min}$. Then, the solution was treated with conc. $\mathrm{NaCl}$ solution and the supernatant was applied into GC-FID FAME (Varian GC 3800, San Diego, CA, USA) detection with CP-Select for FAME column $(100 \mathrm{~m} \times 0.25 \mathrm{~mm})$. FAME standard (Sigma-Aldrich) was applied as a reference. The total SFA content was calculated as the sum of C4:0, C6:0, C8:0, C10:0, C12:0, C14:0, C15:0, C16:0, C18:0, C20:0, C21:0, C22:0, C23:0 and C24:0. The total MUFA content was given as the sum of C15:1, C16:1, C17:1, C18:1, C20:1, C20:3, C22:1, C23:1 and C24:1. For calculating the total PUFA content, the sum of 18:2n6, 18:3n6, 18:3n3, C20:3n6, C20:3n3 and C22:6n3 was used.

\subsection{The Preparation of Meat Samples for Elemental Analysis $\left(\mathrm{HNO}_{3}-\mathrm{H}_{2} \mathrm{O}_{2}\right.$ Digestion)}

From the prepared (ground) meat samples, $1 \mathrm{~g}$ was loaded into digester tubes. Ten $\mathrm{ml}$ of distilled conc. $\mathrm{HNO}_{3}$ was added and heated at $60{ }^{\circ} \mathrm{C}$ for $30 \mathrm{~min}$, then $3 \mathrm{~mL} 30 \%(v / v)$ $\mathrm{H}_{2} \mathrm{O}_{2}$ (Scharlab) was added and the samples were digested further at $120^{\circ} \mathrm{C}$ for $90 \mathrm{~min}$. After the digestion, all samples were washed into $50 \mathrm{~mL}$ volumetric flasks with distilled water, homogenised and filtered (MN $640 \mathrm{~W}$ paper; Macherey-Nagel). The ICP-OES technique was applied on iCAP 7000 spectrophotometer (Thermo Scientific, Cambridge, UK). For the calibration, a multielement standard solution was applied.

\subsection{Amino Acid Analysis}

For total amino acid analysis, $5 \mathrm{mg}$ homogenised samples were hydrolysed with $6 \mathrm{M}$ $\mathrm{HCl}$ at $110^{\circ} \mathrm{C}$ for $23 \mathrm{~h}$. After filtration and dilution to even protein content, the samples were loaded to ion-exchange chromatography on AAA500 (INGOS Ltd., Prague, Czech Republic) semi-automated amino acid analysing system in five buffer systems (citrate -sodium citrate, $\mathrm{pH} 2.2 ; 2.7 ; 3 ; 4.25 ; 8)$ with ninhydrin detection on two wavelengths (440 and $570 \mathrm{~nm}$ ). Cya, Asp, MetS, Thr, Ser and Glu at pH 2.7; Pro, Gly, Ala, Cys and Val at pH 3; Ile and Leu at pH 4.25; and Tyr, Phe, His, Lys and Arg at pH 8 were eluted. Reference amino acid mixture was applied (INGOS Ltd., Prague, Czech Republic).

\subsection{Hydroxyproline Measurement}

The measurement was performed according to the MSZ ISO 3496:2000 standard. Frozen meat was sliced into cubes and wrapped in plastic. It was taken to $70{ }^{\circ} \mathrm{C}$ for $30 \mathrm{~min}$. It was cooled and homogenised. Then, $4 \mathrm{~g}$ of the sample was added to a flask and $30 \mathrm{~mL}$ conc. $\mathrm{H}_{2} \mathrm{SO}_{4}$ was added for hydrolysis. The sample was left for $16 \mathrm{~h}$ at $105^{\circ} \mathrm{C}$. The hydrolysed sample was filtered into a $250 \mathrm{~mL}$ measuring flask with $3 \times 10 \mathrm{~mL}$ hot 
conc. $\mathrm{H}_{2} \mathrm{SO}_{4}$ and diluted up to the $250 \mathrm{~mL}$ mark with distilled water. Four millilitres of the solution was mixed with $2 \mathrm{~mL}$ chloramine T reagent $(1.41(\mathrm{~m} / \mathrm{v}) \%$ sodium-N-chlor- $\mathrm{p}$ toluol-sulphonamide-trihydrate in citrate-sodium acetate buffer, $\mathrm{pH}$ 6.8) and left for $20 \mathrm{~min}$ at RT. Twenty millilitres of the $10(\mathrm{~m} / \mathrm{v}) \% \mathrm{p}$-dimethyl-amino-benzaldehyde in $60(\mathrm{~m} / \mathrm{m}) \%$ perchlorate was added to the solution, mixed thoroughly, closed with a loosened cap and put into a water bath at $60^{\circ} \mathrm{C}$ for $20 \mathrm{~min}$. After heating, the solution was cooled and left at RT for $30 \mathrm{~min}$. The absorbance was determined at $560 \mathrm{~nm}$ in glass cuvettes with water as a reference. The hydroxyproline concentration was determined with a hydroxyproline reference curve $(0.5 \mu \mathrm{g} / \mathrm{mL}-2 \mu \mathrm{g} / \mathrm{mL})$.

\subsection{Examination of Selected Technological Parameters and Shear Force of Meat}

The measured technological characteristics included drip loss (\%), thawing loss (\%), cooking loss (\%) and shear force $(\mathrm{N} / \mathrm{mm})$. For drip loss, meat pieces of $50 \pm 5 \mathrm{~g}$ and $1 \mathrm{~cm}$ thick were cut from each meat part. Pieces were packed in an inflated nylon bag, then hung up in the fridge at $4{ }^{\circ} \mathrm{C}$ for $24 \mathrm{~h}$ and weighed again [23]. The meat samples for cooking loss measurement were cut into $100 \pm 5 \mathrm{~g}$ and $1 \mathrm{~cm}$ thick pieces and weighed. For the evaluation of cooking loss, pieces were packed in nylon bags and cooked for half an hour until core temperature reached $75^{\circ} \mathrm{C}$. The samples were cooled under running water, wiped with a paper towel, and then weighed. After cooking, meat pieces were chilled at $4{ }^{\circ} \mathrm{C}$ overnight. The temperature of the samples was $4{ }^{\circ} \mathrm{C}$ during the measurement. Pieces were cut across the muscle fibres, two times each. XT + Texture Analyser (Warner-Blatzer) was used to measure the shear force $(\mathrm{N} / \mathrm{mm})$ on cooked samples, with shear blade set using $25 \mathrm{~kg}$ load cell, with $1.5 \mathrm{~mm} / \mathrm{s}$ test speed from $40 \mathrm{~mm}$ distance. Once the trigger force is attained, the blade proceeds to shear through the sample. The maximum force denotes the point at which the sample completely fills the triangular cavity of the blade and cuts through the sample surface. After this point, shearing continues through the whole sample until the blade passes through the base plate slot. The blade then returns to its starting position. Curves were evaluated to obtain shear force data.

\subsection{Organoleptic Evaluation of the Different Meat Parts}

After freezing at $-20{ }^{\circ} \mathrm{C}$ for three months, the five samples from the ten birds were cooked for organoleptic evaluation. The cooking procedure was carried out in a pot at $90{ }^{\circ} \mathrm{C}$ until reaching core temperature at $75^{\circ} \mathrm{C}$ [24]. The samples were cut into four pieces of $2 \mathrm{~cm} \times 2 \mathrm{~cm} \times 2 \mathrm{~cm}$ cubes and kept at $45-55^{\circ} \mathrm{C}$ until analysis, which took place immediately after. An experienced panel of eight men and thirteen women aged between 24 and 70 were included in the examination. Four pieces of the five meat parts were placed on each plate but the different meat parts were separated. Each meat part was tasted by four people, so we had two hundred pieces of meat in total. Fresh water and bread were also served to the panellists, who also received a questionnaire with questions about their personal demographical specificities and habits of meat consumption. Having filled in the questionnaire, the panellists commenced the organoleptic evaluation using a 5-point hedonic scale (1-unfavourable, 5-excellent). For organoleptic characteristics, smell, flavour, juiciness, tenderness, texture and the presence of an aftertaste were scored.

\subsection{Statistical Analysis}

The results are presented as mean values and the standard error of the mean. The statistical analysis was carried out with the IBM SPSS Statistics 23.0 and Microsoft Office Excel 2016 programs. Mean values were compared using univariate analysis of variance and a Tukey test with a significance level of $p<0.05$.

\section{Results}

\subsection{The Ratio of Body Parts, Meat Parts and the Main Organs}

The ratio of the main body parts is shown in Table 1 . The skin with feathers made up the greatest part of live weight among the examined body parts (Table 1). The weight of the 
diaphragm and the feet contributed equally to the live weight. The neck was significantly heavier than the head, but lighter than the other body parts. The head made the lowest percentage of all the measured body parts. The total ratio of the evaluated body parts was $16.74 \pm 0.01 \%$ of live weight.

Table 1. The ratio of body parts expressed in the percentage of live weight $(n=10)$.

\begin{tabular}{cc}
\hline Body Parts & Ratio (\%) \\
\hline Skin with feathers & $8.06^{\mathrm{d}} \pm 0.01$ \\
Neck & $2.12^{\mathrm{b}} \pm 0.01$ \\
Diaphragm & $2.86^{\mathrm{c}} \pm 0.01$ \\
Head & $0.71^{\mathrm{a}} \pm 0.01$ \\
Feet & $2.99^{\mathrm{c}} \pm 0.01$ \\
Total & $16.74 \pm 0.01$ \\
\hline
\end{tabular}

$\overline{\mathrm{a}-\mathrm{d}}$ : Different letters represent significant differences $(p<0.05)$.

The ratio of meat parts located on the thigh and back expressed as the percentage of carcass weight is presented in Table 2. The weights in descending order were the following: tip, outside thigh, fan, outside leg, leg, drumstick, other meat cuts, inside leg, oyster, outside strip, back tender, inside strip and medal. The total ratio of all examined lean meat parts was $57.29 \pm 0.59 \%$ and we found significant differences among the muscles. The medal showed the lowest percentage of all, followed by the inside strip, the back tender and the outside strip making the second weight category. The oyster had a significantly higher percentage than the previous cuts. The ratio of the inside leg showed the next weight category, followed by the drumstick and the other meat cuts. The ratio of the fan, outside leg, leg and outside thigh was similar. The tip had the highest percentage of all. The ratio of the outside strip, oyster, tip, outside leg and medal made $19.16 \pm 0.01 \%$ of all the examined meat parts. The owner did not allow us to evaluate the fan as it is the most valuable meat part and is sold whole and only a few birds are slaughtered annually.

Table 2. Percentage of individual valuable meat parts $(n=10)$.

\begin{tabular}{cc}
\hline Meat Part & Ratio (\%) \\
\hline Outside strip & $2.32^{\mathrm{b}} \pm 0.23$ \\
Oyster & $2.72^{\mathrm{c}} \pm 0.09$ \\
Fan & $6.49^{\mathrm{fg}} \pm 0.21$ \\
Tip & $6.83^{\mathrm{g}} \pm 0.26$ \\
Outside leg & $6.34^{\mathrm{f}} \pm 0.13$ \\
Medal & $0.94^{\mathrm{a}} \pm 0.03$ \\
Inside leg & $3.28^{\mathrm{d}} \pm 0.14$ \\
Inside strip & $2.05^{\mathrm{b}} \pm 0.13$ \\
Outside thigh & $6.57^{\mathrm{fg}} \pm 0.21$ \\
Back tender & $2.23^{\mathrm{b}} \pm 0.13$ \\
Leg & $6.28^{\mathrm{f}} \pm 0.17$ \\
Drumstick & $5.70^{\mathrm{e}} \pm 0.21$ \\
Other meat cuts & $5.54^{\mathrm{e}} \pm 0.15$ \\
Total & $57.29 \pm 0.59$ \\
\hline
\end{tabular}

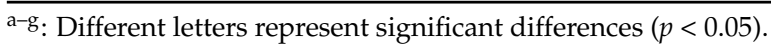

The ratio of the main organs expressed in the percentage of live weight is shown in Table 3. The ratio of heart and lung was similar; neither the liver, nor the empty gizzard differed in the percentage of live weight. The total ratio of the main metabolic organs was $6.16 \pm 0.01 \%$. 
Table 3. Ratio of the main organs expressed in the percentage of live weight $(n=10)$.

\begin{tabular}{cc}
\hline Organs & Ratio (\%) \\
\hline Heart & $0.88^{\mathrm{a}} \pm 0.01$ \\
Lung & $0.98^{\mathrm{a}} \pm 0.01$ \\
Liver & $2.02^{\mathrm{b}} \pm 0.01$ \\
Empty gizzard & $2.28^{\mathrm{b}} \pm 0.01$ \\
Total & $6.16 \pm 0.01$ \\
\hline
\end{tabular}

a,b: Different letters represent significant differences $(p<0.05)$.

\subsection{Chemical Composition of the Examined Meat Parts}

The nutritive composition of the examined meat parts is given in Table 4 . The dry matter content showed values between $23.84 \pm 0.31$ and $26.23 \pm 0.13 \%$. The oyster and the tip showed the lowest dry matter content, with the outside strip showing the highest. The protein content of meat parts took on values between $18.40 \pm 0.09$ and $20.62 \pm 0.16 \%$. The tip showed the lowest protein content, while the outside strip and the medal revealed the highest protein content. The fat content revealed values between $2.36 \pm 0.07$ and $4.50 \pm 1.09 \%$. The oyster had the lowest fat content, while the tip and the outside strip showed the highest fat content. The hydroxyproline content ranged between $0.01 \pm 0.001$ and $0.08 \pm 0.001 \%$. The lowest hydroxyproline content was found for the outside strip and the outside leg; conversely, the tip was the richest in this compound.

Table 4. Nutritive composition of the five examined valuable meat parts $(n=10)$.

\begin{tabular}{ccccc}
\hline Meat Parts/Nutrients & Dry Matter\% $(w / w)$ & Protein $\%(w / w)$ & Fat $\%(w / w)$ & Hydroxyproline\% $(w / w)$ \\
\hline Outside strip & $26.23^{\mathrm{d}} \pm 0.13$ & $20.49^{\mathrm{cd}} \pm 0.08$ & $4.41^{\mathrm{c}} \pm 0.12$ & $0.01^{\mathrm{a}} \pm 0.001$ \\
Oyster & $23.84^{\mathrm{a}} \pm 0.31$ & $20.10^{\mathrm{c}} \pm 0.32$ & $2.36^{\mathrm{a}} \pm 0.07$ & $0.03^{\mathrm{c}} \pm 0.001$ \\
Tip & $24.35^{\mathrm{ab}} \pm 0.15$ & $18.40^{\mathrm{a}} \pm 0.09$ & $4.50^{\mathrm{c}} \pm 1.09$ & $0.08^{\mathrm{d}} \pm 0.001$ \\
Outside leg & $24.51^{\mathrm{b}} \pm 0.15$ & $19.49^{\mathrm{b}} \pm 0.11$ & $3.64^{\mathrm{b}} \pm 0.14$ & $0.01^{\mathrm{a}} \pm 0.001$ \\
Medal & $25.54^{\mathrm{c}} \pm 0.13$ & $20.62^{\mathrm{d}} \pm 0.16$ & $3.57^{\mathrm{b}} \pm 0.11$ & $0.02^{\mathrm{b}} \pm 0.001$ \\
\hline
\end{tabular}

a-d: Different letters represent significant differences $(p<0.05)$.

The amino acid content of the outside strip is presented in Table 5. The amino acid content ranged between $0.15 \pm 0.01$ and $3.33 \pm 0.04 \mathrm{~g} / 100 \mathrm{~g}$ meat. Regarding the amino acid and fatty acid composition, we had the opportunity to assess only one meat part, so we chose the outside strip, which is the second most valuable one after the fan. Among the evaluated amino acids, the essential amino acids showed $8.68 \pm 0.15 \mathrm{~g} / 100 \mathrm{~g}$ meat, the non-essential amino acids made $4.69 \pm 0.27 \mathrm{~g} / 100 \mathrm{~g}$ meat and the quantity of conditional amino acids was $6.18 \pm 0.02 \mathrm{~g} / 100 \mathrm{~g}$ meat. The outside strip was the richest in glutamine and the poorest in cysteine. The quantity of isoleucine, valine and threonine was equal. The examined meat part contained similar concentrations of leucine and lysine. On amino acid content, only Sales's results [8] could be found expressed in $\mathrm{g} / 100 \mathrm{~g}$ meat of unknown meat parts. The author evaluated 10- to 12-month-old ostriches and found lower values for the content of asparagine, threonine, serine, glutamine, alanine, valine, isoleucine, tyrosine, histidine and lysine, while he had no data on proline and cysteine.

In Table 6, we present the main fatty acids which were published in the literature to enable comparison. The total values were calculated using all examined fatty acids. The total saturated fatty acid content of the outside strip was $35.10 \pm 0.53 \%$. The concentration of palmitic acid (C16:0) was the highest of the whole fatty acid composition of all examined saturated fatty acids. Stearic acid (C18:0) was the second fatty acid present in large quantity. The content of monounsaturated fatty acids showed $37.37 \pm 1.52 \%$, of which the concentration of vaccenic acid (C18:1) should be highlighted. The total polyunsaturated fatty acid ratio was $27.54 \pm 1.01 \%$, among which the ratio of linoleic acid (C18:2n6) was the most significant. The total unsaturated fatty acid content was $64.90 \pm 1.68 \%$. Our results, compared to the literature demonstrated in Table 6, agree with the 27 to $39 \%$ range of 
fatty acid ratio published by other authors. The SFA/UFA ratio was below the results of Horbańczuk et al. (1998) [25] and Hoffman et al. (2005) [26], but above that of Horbańczuk et al. (2019) [27]. The $n-6 / n-3$ ratio in our examination was almost half of the one found by Horbańczuk et al. [27]. Information on the diet is not available for drawing further conclusions from the difference.

Table 5. Amino acid composition of outside strip $(n=10)$ compared to the literature.

\begin{tabular}{ccc}
\hline Amino Acids & $\begin{array}{c}\text { Present Results } \\
\text { (g/100 g Meat) }\end{array}$ & $\begin{array}{c}\text { Sales [8] } \\
\text { (g/100 g Meat) }\end{array}$ \\
\hline ASP & $1.94^{\mathrm{m}} \pm 0.02$ & 1.90 \\
THR & $1.00^{\mathrm{i}} \pm 0.01$ & 0.76 \\
SER & $0.83^{\mathrm{e}} \pm 0.01$ & 0.59 \\
GLU & $3.33^{\mathrm{n}} \pm 0.04$ & 2.51 \\
PRO & $0.88^{\mathrm{h}} \pm 0.04$ & - \\
GLY & $0.82^{\mathrm{d}} \pm 0.01$ & 0.82 \\
ALA & $1.18^{\mathrm{k}} \pm 0.01$ & 1.06 \\
CYS & $0.15^{\mathrm{a}} \pm 0.01$ & - \\
VAL & $1.00^{\mathrm{i}} \pm 0.01$ & 0.97 \\
MET & $0.54^{\mathrm{b}} \pm 0.02$ & 0.55 \\
ILE & $0.98^{\mathrm{i}} \pm 0.01$ & 0.92 \\
LEU & $1.62^{\mathrm{l}} \pm 0.02$ & 1.70 \\
TYR & $0.74^{\mathrm{c}} \pm 0.01$ & 0.61 \\
PHE & $0.85^{\mathrm{f}} \pm 0.01$ & 0.94 \\
HIS & $0.86^{\mathrm{g}} \pm 0.01$ & 0.39 \\
LYS & $1.84^{\mathrm{l}} \pm 0.08$ & 1.65 \\
ARG & $1.00^{\mathrm{j}} \pm 0.01$ & 1.36 \\
\hline
\end{tabular}

$\overline{\mathrm{a}-\mathrm{n}}$ : Different letters represent significant differences $(p<0.05)$.

Table 6. Fatty acid composition (\%) in the estimated total sum of fatty acid of ostrich outside strip and that of several authors.

\begin{tabular}{ccccc}
\hline Fatty Acids & $\begin{array}{c}\text { Present Results } \\
(\boldsymbol{n}=\mathbf{1 0})\end{array}$ & $\begin{array}{c}\text { Horbańczuk } \\
\text { et al. (1998) [25] } \\
(\boldsymbol{n}=\mathbf{6})\end{array}$ & $\begin{array}{c}\text { Hoffman et al. } \\
\mathbf{( 2 0 0 5 )}[\mathbf{2 6}]\end{array}$ & $\begin{array}{c}\text { Horbańczuk } \\
\text { et al. (2019) [27] } \\
(\boldsymbol{n}=\mathbf{8})\end{array}$ \\
\hline \multicolumn{4}{c}{ Saturated fatty acids (SFAs) } \\
C8:0 & $0.02^{\mathrm{a}} \pm 0.01$ & $0.03 \pm 0.00$ & - & - \\
C10:0 & $0.05^{\mathrm{a}} \pm 0.02$ & $0.09 \pm 0.01$ & $1.67 \pm 0.45$ & - \\
C12:0 & $1.03^{\mathrm{a}} \pm 0.39$ & $0.14 \pm 0.01$ & $0.00 \pm 0.03$ & - \\
C14:0 & $0.75^{\mathrm{a}} \pm 0.08$ & $1.53 \pm 0.18$ & $0.75 \pm 0.20$ & $0.57 \pm 0.12$ \\
C15:0 & $0.24^{\mathrm{a}} \pm 0.03$ & $-\mathrm{x}$ & $0.11 \pm 0.08$ & $0.02 \pm 0.00$ \\
C16:0 & $22.25^{\mathrm{c}} \pm 1.31$ & $24.06 \pm 0.29$ & $21.95 \pm 0.56$ & $21.37 \pm 0.21$ \\
C18:0 & $10.38^{\mathrm{b}} \pm 1.06$ & $11.84 \pm 0.32$ & $14.08 \pm 0.66$ & $9.81 \pm 0.08$ \\
Total (SFA) & $35.10 \pm 0.53$ & $37.71 \pm 0.39$ & $39.73 \pm 0.77$ & $31.33 \pm 0.21$ \\
\hline \multicolumn{5}{c}{ Monounsaturated fatty acids $($ MUFAs) } \\
C14:1 & $<0.01^{*}$ & - & & - \\
C15:1 & $<0.01^{*}$ & - & $0.12 \pm 0.07$ & $0.17 \pm 0.01$ \\
C16:1 & $5.33^{\mathrm{b}} \pm 0.52$ & $3.79 \pm 0.11$ & $3.51 \pm 0.42$ & $7.90 \pm 0.09$ \\
C18:1 & $31.85^{\mathrm{c}} \pm 1.20$ & $33.25 \pm 0.52$ & $21.15 \pm 0.78$ & $29.96 \pm 0.15$ \\
C20:1 & $<0.01^{*}$ & $0.29 \pm 0.01$ & $1.96 \pm 0.57$ & $0.21 \pm 0.02$ \\
Total (MUFA) & $37.37 \pm 1.52$ & $33.49 \pm 0.40$ & $27.27 \pm 1.13$ & $38.46 \pm 0.16$ \\
\hline
\end{tabular}


Table 6. Cont.

\begin{tabular}{ccccc}
\hline Fatty Acids & $\begin{array}{c}\text { Present Results } \\
(\boldsymbol{n}=\mathbf{1 0})\end{array}$ & $\begin{array}{c}\text { Horbańnczuk } \\
\text { et al. (1998) [25] } \\
(\boldsymbol{n}=\mathbf{6})\end{array}$ & $\begin{array}{c}\text { Hoffman et al. } \\
(\mathbf{2 0 0 5})[26]\end{array}$ & $\begin{array}{c}\text { Horbańczuk } \\
\text { et al. }(\mathbf{2 0 1 9 )}[\mathbf{2 7}] \\
(\boldsymbol{n}=\mathbf{8})\end{array}$ \\
\hline \multicolumn{4}{c}{ Polyunsaturated fatty acids (PUFAs) } \\
C18:2n6 & $21.19^{\mathrm{d}} \pm 0.61$ & $15.01 \pm 0.55$ & $18.06 \pm 0.84$ & $18.70 \pm 0.10$ \\
C18:3n3 & $1.49^{\mathrm{b}} \pm 0.11$ & $6.50 \pm 0.52$ & $5.76 \pm 0.36$ & $1.98 \pm 0.04$ \\
C18:3n6 & $<0.01^{*}$ & - & $0.59 \pm 0.16$ & - \\
C20:3n6 & $<0.01^{*}$ & - & - & $0.57 \pm 0.01$ \\
C20:3n3 & $4.85^{\mathrm{c}} \pm 1.10$ & $5.30 \pm 0.13$ & $6.15 \pm 0.77$ & $5.44 \pm 0.05$ \\
C22:6n3 & $<0.01^{*}$ & $0.73 \pm 0.05$ & $1.22 \pm 0.55$ & $0.67 \pm 0.02$ \\
Total (PUFA) & $27.54 \pm 1.01$ & $28.79 \pm 0.61$ & $32.99 \pm 1.22$ & $28.48 \pm 0.10$ \\
n-6/n-3 ratio & $3.91 \pm 0.43$ & - & - & $7.55 \pm 0.21$ \\
SFA/UFA ratio & $0.54 \pm 0.02$ & 0.61 & 0.66 & 0.47 \\
\hline
\end{tabular}

$\overline{\mathrm{a}-\mathrm{d} \text { : Different letters represent significant differences }(p<0.05) ;{ }^{*} \text { values below the level of detection; }{ }^{\mathrm{x}} \text { not }}$ presented in the study.

The mineral composition of the outside strip is shown in Table 7. The content of $\mathrm{Ca}, \mathrm{K}$, $\mathrm{Mg}, \mathrm{Na}$ and $\mathrm{P}$ was significantly the greatest among all examined minerals. Our results for all the examined minerals except for Mn surpassed the literature data presented in Table 7. In comparison with the studies, differences in the content of $\mathrm{Ca}$ and $\mathrm{K}$ were the greatest. The authors also revealed remarkably different results in some cases.

Table 7. Mineral composition of ostrich outside strip $(n=10)$ compared to the literature.

\begin{tabular}{cccc}
\hline Minerals & $\begin{array}{c}\text { Present Results } \\
(\mathbf{g} / \mathbf{1 0 0} \mathbf{g})\end{array}$ & $\begin{array}{c}\text { Majewska [28] } \\
\mathbf{( g / 1 0 0 ~} \mathbf{g})\end{array}$ & $\begin{array}{c}\text { Sales and Oliver-Lyons } \\
\text { [29] } \mathbf{( g / 1 0 0 ~} \mathbf{g})\end{array}$ \\
\hline $\mathrm{Ca}$ & $0.33^{\mathrm{b}} \pm 0.007$ & $0.05 \pm 0.008$ & 0.08 \\
$\mathrm{Cu}$ & $0.002^{\mathrm{a}} \pm 0.0001$ & $0.001 \pm 0.0003$ & 0.001 \\
$\mathrm{Fe}$ & $0.04^{\mathrm{a}} \pm 0.0006$ & $0.04 \pm 0.005$ & 0.02 \\
$\mathrm{~K}$ & $3.45^{\mathrm{b}} \pm 0.05$ & $2.38 \pm 0.14$ & 2.69 \\
$\mathrm{Mg}$ & $0.26^{\mathrm{b}} \pm 0.003$ & $0.25 \pm 0.01$ & 0.22 \\
$\mathrm{Mn}$ & $0.0004^{\mathrm{a}} \pm 0.00001$ & $0.0002 \pm 0.00003$ & 0.0006 \\
$\mathrm{Na}$ & $0.51^{\mathrm{b}} \pm 0.01$ & $0.33 \pm 0.03$ & 0.43 \\
$\mathrm{P}$ & $2.48^{\mathrm{b}} \pm 0.01$ & $2.28 \pm 0.12$ & 2.13 \\
$\mathrm{Zn}$ & $0.03^{\mathrm{a}} \pm 0.0008$ & $0.02 \pm 0.006$ & 0.02 \\
\hline
\end{tabular}

a,b: Different letters represent significant differences $(p<0.05)$.

\subsection{Colour and $p H$ Value of the Examined Valuable Meat Parts}

Table 8 presents the colour and $\mathrm{pH}$ value of the five examined meat parts. No significant difference was found between the meat parts in $\mathrm{L}^{*}$ value. However, the $\mathrm{a}^{*}$ and $\mathrm{b}^{*}$ planes were more sensitive $(p<0.05)$ to the colour determinations. Only the $\mathrm{a}^{*}$ value of outside leg differed from $\mathrm{a}^{*}$ value of the other meat parts and proved to be the smallest. The outside leg showed the smallest, the oyster the greatest $b^{*}$ value. The $\mathrm{pH}$ value of the examined meat parts ranged between $5.95 \pm 0.02$ and $6.01 \pm 0.03$ and we found no significant difference among the muscles.

Table 8. The colour and the $\mathrm{pH}^{24 \mathrm{~h}}$ value of the five examined valuable meat parts $(n=10)$.

\begin{tabular}{ccccc}
\hline $\begin{array}{c}\text { Meat } \\
\text { Parts/Parameters }\end{array}$ & $\mathbf{L}^{*}$ & $\mathbf{a}^{*}$ & $\mathbf{b}^{\mathbf{*}}$ & $\mathbf{p H}^{\mathbf{2 4 h}}$ \\
\hline Outside strip & $36.76 \pm 0.92$ & $25.61^{\mathrm{b}} \pm 0.32$ & $6.15^{\mathrm{bcd}} \pm 0.38$ & $5.95 \pm 0.02$ \\
Oyster & $35.47 \pm 0.93$ & $24.85^{\mathrm{b}} \pm 0.47$ & $6.59^{\mathrm{d}} \pm 0.32$ & $6.00 \pm 0.04$ \\
Tip & $36.66 \pm 0.73$ & $25.38^{\mathrm{b}} \pm 0.46$ & $5.75^{\mathrm{bcd}} \pm 0.38$ & $6.01 \pm 0.03$ \\
Outside leg & $35.81 \pm 0.82$ & $22.60^{\mathrm{a}} \pm 0.58$ & $3.36^{\mathrm{a}} \pm 0.51$ & $5.97 \pm 0.01$ \\
Medal & $37.04 \pm 0.67$ & $24.75^{\mathrm{b}} \pm 0.35$ & $5.29^{\mathrm{bc}} \pm 0.30$ & $6.00 \pm 0.02$ \\
\hline
\end{tabular}

Different letters represent significant differences $(p<0.05)$. 


\subsection{Selected Technological Parameters and Shear Force of the Five Examined Valuable Meat Parts}

The values of the technological parameters and shear force are shown in Table 9. We found no significant difference between the results of drip loss; however, differences in thawing loss were significant. The outside leg and medal showed the smallest thawing loss, while the outside strip and the oyster showed the biggest. It can be stated that the outside leg and the medal were less negatively affected by thawing, and these meat parts could hold water more efficiently after the process. The cooking loss showed values between $36.63 \pm 1.38$ and $41.23 \pm 1.47 \%$ and we could not detect significant differences among meat parts. The shear force took on values between $2.90 \pm 0.24$ and $3.42 \pm 0.37 \mathrm{~N} / \mathrm{mm}$. There was no significant difference among the meat parts.

Table 9. Technological characteristics and shear force of the five valuable meat parts $(n=10)$.

\begin{tabular}{ccccc}
\hline Meat Parts & Drip Loss $\mathbf{( \% )}$ & $\begin{array}{c}\text { Thawing Loss } \\
\mathbf{( \% )}\end{array}$ & $\begin{array}{c}\text { Cooking Loss } \\
\mathbf{( \% )}\end{array}$ & $\begin{array}{c}\text { Shear Force } \\
\mathbf{( N / m m )}\end{array}$ \\
\hline Outside strip & $5.88 \pm 0.02$ & $4.22^{\mathrm{b}} \pm 0.01$ & $41.23 \pm 1.47$ & $2.99 \pm 0.25$ \\
Oyster & $4.02 \pm 0.01$ & $4.48^{\mathrm{b}} \pm 0.01$ & $37.32 \pm 1.30$ & $3.01 \pm 0.24$ \\
Tip & $4.00 \pm 0.01$ & $3.50^{\mathrm{ab}} \pm 0.01$ & $40.05 \pm 1.23$ & $3.28 \pm 0.23$ \\
Outside leg & $4.17 \pm 0.01$ & $2.72^{\mathrm{a}} \pm 0.01$ & $36.63 \pm 1.38$ & $3.42 \pm 0.37$ \\
Medal & $4.08 \pm 0.01$ & $2.32^{\mathrm{a}} \pm 0.01$ & $36.68 \pm 1.30$ & $2.90 \pm 0.24$ \\
\hline
\end{tabular}

Different letters represent significant differences $(p<0.05)$.

\subsection{Organoleptic Characteristics of the Examined Meat Parts}

The results of the organoleptic evaluation are given in Table 10. Only the flavour and the tenderness revealed significant differences between the meat parts. The oyster and the medal were less favourable, while the outside strip and the tip had the best flavour and tenderness. Although we could not find significant differences in shear force among the meat parts, panellists found significant deviations in meat tenderness. Aftertaste (metallic, unfavourable, uncharacteristic of meat) was not detected. In summary, ostrich meat received an average score for every organoleptic parameter.

Table 10. Organoleptic characteristics of the examined valuable meat parts $(n=10)$.

\begin{tabular}{ccccccc}
\hline Meat Parts & Smell & Flavour & Juiciness & Tenderness & Texture & Aftertaste \\
\hline Outside strip & $3.22 \pm 0.14$ & $3.42^{\mathrm{b}} \pm 0.14$ & $3.37 \pm 0.13$ & $3.05^{\mathrm{b}} \pm 0.14$ & $2.93 \pm 0.14$ & $1.90 \pm 0.05$ \\
Oyster & $2.85 \pm 0.14$ & $2.88^{\mathrm{a}} \pm 0.14$ & $3.37 \pm 0.13$ & $2.85^{\mathrm{ab}} \pm 0.14$ & $2.63 \pm 0.14$ & $1.88 \pm 0.05$ \\
Tip & $3.21 \pm 0.14$ & $3.36^{\mathrm{b}} \pm 0.14$ & $3.57 \pm 0.12$ & $3.05^{\mathrm{b}} \pm 0.14$ & $2.67 \pm 0.14$ & $1.93 \pm 0.05$ \\
Outside leg & $3.19 \pm 0.14$ & $3.07^{\mathrm{ab}} \pm 0.14$ & $3.41 \pm 0.12$ & $2.52^{\mathrm{a}} \pm 0.14$ & $2.45 \pm 0.14$ & $1.95 \pm 0.05$ \\
Medal & $3.00 \pm 0.14$ & $2.98^{\mathrm{a}} \pm 0.14$ & $3.33 \pm 0.12$ & $2.71^{\mathrm{ab}} \pm 0.14$ & $2.76 \pm 0.14$ & $1.91 \pm 0.05$ \\
\hline
\end{tabular}

Different letters represent significant differences $(p<0.05)$.

\section{Discussion}

\subsection{The Ratio of Body Parts, Meat Parts and the Main Organs}

Although the feed given in our study contained the recommended quantity of energy, it was richer in protein, fat and lysine in comparison with the literature data [10]. The birds slaughtered at 18 months of age had similar live weight to that of the younger (10-14 months) animals. However, after 12 months of age, fattening becomes less economic $[6,7]$. The skin and feather represented a significant proportion of slaughter weight. These body parts are considered valuable products on the western market [30]. The head, the feet and the diaphragm are regarded as inedible body parts since they contain mostly bones. The neck is worthless from the consumers' point of view. It is usually purchased by zoos. The live weight of 12-14-month-old Zimbabwean blue neck ostriches was $103.72 \mathrm{~kg}$ in the study of Dijana et al. [31]. The ratios of the skin, neck and head of the slaughtered birds were similar to those of the 18-month-old birds in our study. Morris et al. [11] examined fourteen ostriches between 10 to 14 months of age with $95.54 \mathrm{~kg}$ live weight and drew similar conclusions. The authors presented a moderately higher proportion of head $(1.78 \%)$ 
and lower feet $(2.51 \%)$. Data on genotype and nutrition were not available. Regarding meat parts, the weight of the outside strip, the oyster, the tip and the outside leg was $0.10-0.53,0.08-0.29,0.31-1.17$ and $0.19-1.16 \mathrm{~kg}$, respectively [32]. The lower values of the range stemmed from 7-month-old ostriches, the higher values represented 18-month-old birds. Results from the same age were far below what we experienced for the same meat parts. Data on genotype and nutrition were not published.

The weight of the empty gizzard, heart, liver and lung or lung with trachea of 12-14 months old ostriches ranged between 2.11-4.39\%, 0.90-0.97, 0.54-0.56 and $0.42-1.29 \%$ [11,31]. When the organ weight of the 10-month-old and 14-month-old birds was compared, the biggest differences were observed in those of the lung and gizzard. In the present study, the weight of the same organs showed $2.28 \pm 0.01,0.88 \pm 0.01$, $2.02 \pm 0.01$ and $0.98 \pm 0.01 \%$, respectively. Differences due to the age of the birds $(12,14$ and 18 months) could be found in the weight of the liver since 18-month-old ostriches in our examination had four times heavier liver than the 12- to 14-month-old ones in the literature. The large size of the liver enables the sufficient metabolism of nutrients, vitamin and glycogen storage and the detoxification of the organism. The extensive ratio of the empty gizzard can be interpreted by its high capacity because ostriches swallow small pebbles to facilitate digestion.

\subsection{Chemical Composition of the Examined Meat Parts}

For the colour, $\mathrm{L}^{*}$ defines black at 0 and white at 100 . In the $\mathrm{a}^{*}$ value, green is closer to -120 and red is closer to +120 , in $b^{*}$, blue takes the value of -120 and yellow shows +120 [22,31]. Species, breed, age, sex, nutrition, rearing, total haem and myoglobin content, storage time, $\mathrm{pH}$ and processing parameters also influence meat colour [33]. Meat with high pigmentation and after oxidation offers lower $L^{*}, a^{*}$ and $b^{*}$ values [33]. The $L^{*}, a^{*}$ and $\mathrm{b}^{*}$ for the tip of ten 10- to 12-month-old Zimbabwean blue neck ostriches were $32.6 \pm 2.46$, $16.9 \pm 1.84$ and $11.4 \pm 1.22$ [28], compared to our results of $36.66 \pm 0.73,25.38 \pm 0.46$ and $5.75 \pm 0.38$ for the same meat part. The cited authors determined lower values for $\mathrm{L}^{*}$ and $\mathrm{a}^{*}$ and higher for $b^{*}$, indicating a darker meat part. The birds in their research were younger; however, data on nutrition and rearing conditions were not available.

The final postmortem $\mathrm{pH}$ values of meat and drip loss are significantly and negatively correlated parameters. Higher $\mathrm{pH}$ (over 5.7) results in stronger water-holding capacity, but shorter shelf life. Higher $\mathrm{pH}$ value improves water-holding capacity and so decreases drip loss [18]. The mean $\mathrm{pH}$ value of ostrich meat is 7.2, but it decreases after $24 \mathrm{~h}$ and facilitates meat processing [19]. Generally speaking, ostrich meat has a regular $(<5.8)$ to high (>6.2) $24 \mathrm{~h}$ postmortem $\mathrm{pH}$ [1]. Our results were slightly below the $\mathrm{pH}_{24} 6.12$ for the inside leg and $6.11 \pm 0.03$ for an unknown meat part $[1,34]$, but above the value of 5.81 for the fan [35]. In summary, ostrich meat has a naturally higher postmortem $\mathrm{pH}$ than the 5.7-5.9 generally detected in meat, which results in better water-holding capacity, but shorter shelf life. With chicken, $\mathrm{pH}_{24}$ significantly increases by bird age [36] but there are no data published on ostrich.

In comparison with our results on chemical composition, Sharaf et al. [37] demonstrated a $1.01 \%$ lower dry matter, a $1.33 \%$ higher protein and a $2.05 \%$ lower fat content and claimed that the dry matter, protein and fat content of ostrich fan from three 12-monthold ostriches were $23.88,21.15$ and $1.65 \%$, respectively. The higher protein and lower fat content of the meat can be interpreted by the fact that they used six-month-younger birds in their study. However, no data are available on nutrition. The protein content of the inside leg, tip and fan deriving from seven 12- to 14-month-old ostriches showed $21.6 \pm 0.49,20.81 \pm 0.72$ and $21.0 \pm 0.58 \%$ [38]. Our result for the tip was $2.41 \%$ lower than that observed by the authors. Their findings for all the examined meat parts show higher values than any meat part in our research. This fact can be interpreted by the age of the birds as younger ostriches were examined in their study. Data on nutrition were not available. The meat of rhea contains $25.9 \%$ dry matter, $22.5 \%$ protein and $1.6 \%$ fat [39-41], which indicates a higher dry matter and protein and a lower fat content when compared 
to our results. The same parameters in emu were 25.2, 22.3 and $1.8 \%$ [33]. Regarding the literature and our findings, it can be concluded that emu and rhea meat contain more dry matter and protein, but less fat than ostrich meat. The hydroxyproline content of meat determines meat tenderness. The lower the hydroxyproline content in meat, the more tender it is. The hydroxyproline content of ostrich meat is $0.09 \%$ [34], which is higher than the value we determined, providing more tender meat. Data on sample size, age of the bird and the examined meat parts were not available.

In respect of amino acid content, values in the research of Sales [8] were lower for threonine, serine, glutamine, isoleucine, alanine, valine, isoleucine, tyrosine, histidine and lysine for ostrich unknown meat parts as compared to our results on the outside strip. Sales and Hayes [38] examined the tip with $21.0 \%$ protein content and found essential and non-essential amino acid content to be $8.47 \mathrm{~g} / 100 \mathrm{~g}$ meat and $10.09 \mathrm{~g} / 100 \mathrm{~g}$ meat. We presented higher essential amino acid content (8.68 $\pm 0.15 \mathrm{~g} / 100 \mathrm{~g}$ meat), but lower nonessential amino acid content $(4.69 \pm 0.27 \mathrm{~g} / 100 \mathrm{~g}$ meat $)$ when compared to the literature. Data on the amino acid composition of the outside strip were not available in the literature. Differences could be attributed to the different diets and ages of the animals. However, the description of the feed was not available in the literature. In addition, there was no information on the influence of ostrich age for this parameter.

Horbańczuk et al. [25] examined the fan and leg deriving from six Zimbabwean blue neck 12-month-old ostriches and reported SFA content being $37.71 \pm 0.39 \%$ for the fan, and $39.37 \pm 0.45 \%$ for the leg. The PUFA content of the fan and leg was $28.79 \pm 0.61$ and $23.78 \pm 0.33 \%$ of total fatty acids. The authors did not find a significant difference between the meat parts. The SFA content was higher for both examined meat parts as compared to our results for the outside strip $(35.10 \pm 0.53 \%)$. The PUFA content of the fan was higher, while that of the leg was lower than it was found in our study for the outside strip (27.54 $\pm 1.01 \%)$. It can be argued that the meat from older birds shows lower SFA content than that of the younger ones. Conversely, differences between PUFA values are not obvious enough to draw further conclusions from the effect of the age of the bird on PUFA content. Data on nutrition were not available. The SFA content of the fan from ostriches of unknown ages was $39.73 \pm 0.77$ [26], which is $4 \%$ more than the value we established for the outside strip $(35.10 \pm 0.53 \%)$. The PUFA content was reported to be $5 \%$ higher $(32.99 \pm 1.22 \%)$ than our results for the outside strip $(27.54 \pm 1.01 \%)$, although in the study [26] unrefined fish oil diet supplementation was provided for the birds. Our research presented the $n-6 / n-3$ ratio to be $3.91 \pm 0.43$, which is higher than the 3.02 for ostrich in general [42], but lower than the $7.55 \pm 0.12$ [27] in the fan. The saturated and unsaturated fatty acid composition of the ostrich fan is $48.0 \pm 1.9$ and $50.8 \pm 1.9 \%$ [43]. The authors found higher saturated but lower unsaturated fatty acid content and SFA/UFA ratio in comparison with our results $(35.10 \pm 0.53 \%, 64.90 \pm 1.68 \%$ and $0.54 \pm 0.017)$. In their findings, the SFA/UFA ratio was $0.9 \pm 0.4$ for the ostrich fan. The meat was the richest in palmitic acid, oleic acid and linoleic acid. The SFA/UFA ratio was higher $(0.9 \pm 0.4)$ in their study for the fan than what we found in the ostrich outside strip (0.54 \pm 0.02$)$. The ostrich meat was the richest in palmitic acid, oleic acid and linoleic acid. The SFA/UFA ratio was higher in their study than our findings for the ostrich outside strip $(0.54 \pm 0.02)$. In another examination on 12-month-old rheas, the SFA, MUFA and PUFA content of the inside leg was $27.93 \pm 0.7 \%, 42.36 \pm 2.5$ and $29.71 \pm 1.9 \%$, respectively [44]. The authors found lower SFA, MUFA and PUFA content; in addition, the n-6/n-3 ratio was also higher $(31.30 \pm 9.0)$ in comparison with our result on ostrich outside strip (3.91 \pm 0.43$)$. Nutrition data were not published. The PUFA content of ostrich meat is $8 \%$ higher than emu meat but $5 \%$ lower than rhea meat [45].

The Ca, P and $\mathrm{Zn}$ content of raw ostrich meat is $0.90 \pm 0.003,6.30 \pm 0.07$ and $0.10 \pm 0.002 \mathrm{~g} / 100 \mathrm{~g}$ [34]. Horbańczuk and Wierczbicka [42] claimed that the Ca content of emu and ostrich meat varies between 0.05 and $0.07 \mathrm{~g} / 100 \mathrm{~g}$, respectively. We found the same elements to be present in $0.33 \pm 0.007,2.48 \pm 0.01$ and $0.03 \pm 0.0008 \mathrm{~g} / 100 \mathrm{~g}$ in the outside strip. Neither the age nor the nutrition of the birds was mentioned in the study. 
The Fe content of ratite meat is $0.04 \mathrm{~g} / 100 \mathrm{~g}$ [42]. We experienced a higher value for this parameter in the outside strip $(0.04 \pm 0.0006 \mathrm{~g} / 100 \mathrm{~g})$. The $\mathrm{Mg}$ and Na content of ostrich meat was as considered $0.22 \mathrm{~g} / 100 \mathrm{~g}$ and $0.43 \mathrm{~g} / 100 \mathrm{~g}$ [29], respectively. Selenium showed a value of $0.0004 \pm 0.00001 \mathrm{~g} / 100 \mathrm{~g}$. The content of Mg content of the outside strip was lower $(0.26 \pm 0.003 \mathrm{~g} / 100 \mathrm{~g})$ and the content of Na was higher $(0.51 \pm 0.01 \mathrm{~g} / 100 \mathrm{~g})$ in our research in comparison to the relevant literature.

\subsection{Selected Technological Parameters, Shear Force and Organoleptic Characteristics of the Five Examined Valuable Meat Parts}

The cooking loss and drip loss of ostrich meat of unknown origin were 21.18 and $2.85 \%$, respectively [33]. In the study, there was no significant difference between the meat parts. The thawing loss $(3.88 \pm 0.42 \%)$ of tip was the greatest in every examined meat part [31]. Their examination revealed greater loss for the tip than our study. Cooking loss and shear force of the inside leg from ostriches of 12 months of age were $37.4 \%$ and $3.35 \mathrm{~N} / \mathrm{mm}$ [46]. The cooking loss showed values closest to the oyster in our study $(37.32 \pm 1.30 \%)$, but higher than the inside leg and medal, and lower than the outside strip and tip. Even though birds in their study were half a year younger than in our research, the meat was firmer as compared to every meat part in our examination except for the outside leg (3.42 \pm 0.3$)$. For emus, the shear force is $2.95 \mathrm{~N} / \mathrm{mm}$, providing more tender meat as compared to ostriches [33]. The cooking loss of rhea meat is $41.9 \%$, which is more than in ostrich [34].

Different meat parts from ostriches of unknown age were scored on a 9-point hedonic scale. The leg (outside leg, mid-leg and inside leg) was considered to have the most intense flavour [47]. In another experiment on a 9-point hedonic scale, meat flavour, tenderness and juiciness scored $6.80 \pm 0.05,7.17 \pm 0.06$ and $7.38 \pm 0.12$ [34], which meant that the judges liked ostrich meat moderately. The flavour of the meat was not significantly affected by the age of the birds [17]. Regarding our results, we found statistical differences in flavour and tenderness between the meat parts. The outside strip and tip had the best flavour (with scores $3.42 \pm 0.14$ and $3.36 \pm 0.14$ ) and tenderness (with scores $3.05 \pm 0.14$ and $3.05 \pm 0.14)$.

In our analyses in respect to the organoleptic evaluation, the oyster and the medal were less favourable, while the outside strip and the tip had the best flavour and tenderness.

\section{Conclusions}

Ostrich meat can play a role as an alternative food resource in human nutrition. We aimed to conduct a study including meat parts that are considered valuable in Hungary. Concerning the amino acid composition, glutamine should be highlighted. Our results show that ostrich meat generally has low saturated fatty acid content, a low SFA/UFA and $n-6 / n-3$ ratio and high polyunsaturated fatty acid content. Ostrich meat is dark red and we could prove that it is rich in minerals. Comparing the examined valuable meat parts, the protein content of the medal was the highest. Regarding $L^{*} a^{*} b^{*}$ meat colour, the meat parts significantly differed in $a^{*}$ and $b^{*}$ values. The outside leg had the lowest $a^{*}$ and $b^{*}$ values. As for technological characteristics, the outside strip and the oyster significantly had the greatest thawing loss. According to the panellists, cooked ostrich meat did not have an aftertaste and it received an average score for all the evaluated organoleptic parameters. In comparison with the younger birds (10-14 months of age) in the literature, the 18-month-old ostriches in our study showed similar or slightly lower slaughter yield, lighter meat, greater liver weight, lower protein and higher fat content, higher essential amino acid and lower non-essential amino acid content and higher SFA content in some cases.

Author Contributions: Conceptualisation, L.D.B., Z.V., I.K., T.P. and V.S.; methodology, Z.V., T.P., I.K. and L.D.B.; software, I.K. and L.D.B.; validation, L.D.B., I.K., Z.V. and T.P.; formal analysis, L.D.B.; writing—original draft preparation, L.D.B.; writing—review and editing, L.D.B., T.P., Z.V. and I.K.; visualisation, I.K., Z.V. and L.D.B.; supervision, I.K., Z.V. and T.P. All authors have read and agreed to the published version of the manuscript. 
Funding: The publication is supported by the EFOP-3.6.3-VEKOP-16-2017-00008 project. The project is co-financed by the European Union and the European Social Fund.

Institutional Review Board Statement: Not applicable.

Informed Consent Statement: Not applicable.

Data Availability Statement: The data presented in this study are available on request from the corresponding author. The data are not publicly available due to privacy.

Conflicts of Interest: The authors declare no conflict of interest.

\section{References}

1. Poławska, E.; Marchewska, J.; Cooper, R.; Pomianowski, J.; Strzałkowska, N.; Horbańczuk, J.; Sartowska-Żygowska, K. The ostrich meat-An updated review. II. Nutritive value. An. Sci. Pap. Rep. 2011, 29, 89-97.

2. Al-Khalifa, H.; Al-Naser, A. Ostrich meat: Production, quality parameters, and nutritional comparison to other types of meats. J. Appl. Poult. Res. 2014, 23, 784-790. [CrossRef]

3. Harris, I.; Morris, C.; Jackson, T.; May, S.; Lucia, L.; Hale, D.; Miller, R.; Keeton, J.; Savell, J.; Acuff, G. Ostrich Meat Industry Development. Texas A\&M University System, Texas. Fin. Rep. Am. Ost. Ass. 1993, 1, 1-44.

4. Balog, A.; Almeida, P.I.C.L. Ostrich (Struthio camelus) carcass yield and meat quality parameters. Braz. J. Poult. Sci. 2007, 9, 215-220. [CrossRef]

5. Al-Nasser, A.; Al-Khalaifa, H.; Holleman, K.; Al-Ghalaf, W. Ostrich production in the arid environment of Kuwait. J. Arid. Environ. 2003, 54, 219-224. [CrossRef]

6. Cooper, R.G. Critical factors in ostrich production: A focus on Southern Africa. W. Poult. Sci. J. 2000, 56, 247-265. [CrossRef]

7. Pollok, K.D.; Hale, D.S.; Miller, R.K.; Angel, R.; Blue-Mclendon, A.; Baltmanis, B.; Keeton, J.T. Ostrich slaughter and by-product yields. Am. Ost. 1997, 4, 31-35.

8. Sales, J. Ostrich meat research: An update. In Proceedings of the World Ostrich Congress, Warsaw, Poland, 26-29 September 2002; pp. 148-160.

9. Hoffman, L.; Botha, S.S.; Britz, T. Sensory properties of hot-deboned ostrich (Struthio camelus var. domesticus) Muscularis gastrocnemius, pars interna. Meat Sci. 2006, 72, 734-740. [CrossRef]

10. Aganga, A.A.B.; Aganga, A.O.; Omphile, U.J. Ostrich feeding and nutrition. Pak. J. Nutr. 2003, 2, 60-67.

11. Morris, C.A.; Harris, S.D.; May, S.G.; Jackson, T.C.; Hale, D.S.; Miller, R.K.; Keeton, J.T.; Acuff, G.R.; Lucia, L.M.; Savell, J. Ostrich Slaughter and Fabrication: 1. Slaughter Yields of Carcasses and Effects of Electrical Stimulation on Post-Mortem pH. Poult. Sci. 1995, 74, 1683-1687. [CrossRef]

12. Fernández-López, J.; Sayas-Barberá, E.; Muñoz, T.; Sendra, E.; Navarro, C.; Pérez-Alvarez, J.A. Effect of packaging conditions on shelf-life of ostrich steaks. Meat Sci. 2008, 78, 143-152. [CrossRef]

13. Váry, M.; Holló, G.; Ábrahám, C.; Csapó, J.; Seenger, J.; Holló, I.; Szúcs, E. Az íz szerepe a hús élvezeti értékében (Irodalmi áttekintés). Acta Agr. Kap. 2003, 7, 63-74.

14. Taylor, G.; Andrews, L.; Gillespie, J.; Schupp, A.; Prinyawiwatkul, W. How do ratite meats compare with beef? Implications for ratites industry. J. Agribus. 1998, 16, 97-114.

15. Hoffman, L.; Fisher, P. Comparison of meat quality characteristics between young and old ostriches. Meat Sci. 2001, 59, 335-337. [CrossRef]

16. Swatland, H.J. On-Line Evaluation of Meat; Technomic Pub. Co.: Lancaster, PA, USA, 1995; pp. 1-372. ISBN 978-1-56676-333-2.

17. Botha, S.S.C.; Hoffman, L.C.; Britz, T.C. Effect of hot-deboning on the physical quality characteristics of ostrich meat. S. Afr. J. An. Sci. 2006, 36, 197-208.

18. Thomas, A.R.; Gondoza, H.; Hoffman, L.; Oosthuizen, V.; Naudé, R.J. The roles of the proteasome, and cathepsins B, L, H and D, in ostrich meat tenderisation. Meat Sci. 2004, 67, 113-120. [CrossRef] [PubMed]

19. Fernández-López, J.; Jiménez, S.; Sayas-Barberá, E.; Sendra, E.; Pérez-Alvarez, J.A. Quality characteristics of ostrich (Struthio camelus) burgers. Meat Sci. 2006, 73, 295-303. [CrossRef]

20. Cooper, R.; Mahrose, K. Anatomy and physiology of the gastro-intestinal tract and growth curves of the ostrich (Struthio camelus). An. Sci. J. 2004, 75, 491-498. [CrossRef]

21. Csiro, P. Model Code of Practice for the Welfare of Animals: Livestock at Slaughtering Establishments; Csiro Publishing: Victoria, Australia, 2003. Available online: https:/ / www.publish.csiro.au/book/2975 (accessed on 10 May 2021).

22. Hernández Salueña, B.; Sáenz Gamasa, C.; Diñeiro Rubial, J.M.; Alberdi Odriozola, C. CIELAB color paths during meat shelf life. Meat Sci. 2019, 157, 107-889. [CrossRef]

23. Honikel, K.O. Reference methods for the assessment of physical characteristics of meat. Meat Sci. 1998, 49, 447-457. [CrossRef]

24. Bejerholm, C.; Aaslyng, M.D. The influence of cooking technique and core temperature on results of a sensory analysis of pork-depending on the raw meat quality. Food Qual. Prefer. 2004, 15, 19-30. [CrossRef]

25. Horbañczuk, J.; Sales, J.; Celeda, T.; Celeda, A.; Ziêba, G.; Kawka, P. Cholesterol content and fatty acid composition of ostrich meat as influenced by subspecies. Meat Sci. 1998, 50, 385-388. 
26. Hoffman, L.C.; Joubert, M.; Brand, T.S.; Manley, M. The effect of dietary fish oil rich in n-3 fatty acids on the organoleptic, fatty acid and physicochemical characteristics of ostrich meat. Meat Sci. 2005, 70, 45-53. [CrossRef]

27. Horbańczuk, O.K.; Moczkowska, M.; Marchewka, J.; Atanasov, A.G.; Kurek, M.A. The Composition of Fatty Acids in Ostrich Meat Influenced by the Type of Packaging and Refrigerated Storage. Molecules 2019, 24, 4128. [CrossRef]

28. Majewska, D.; Jakubowska, M.; Ligocki, M.; Tarasewicz, Z.; Szczerbińska, D.; Karamucki, T.; Sales, J. Physicochemical characteristics, proximate analysis and mineral composition of ostrich meat as influenced by muscle. Food Chem. 2009, 117, $207-211$. [CrossRef]

29. Sales, J.; Oliver-Lyons, B. Ostrich meat: A review. Food Aust. 1996, 48, 504511.

30. Bitlisli, B.O.; Başaran, B.; Sari, Ö.; Ahmet, A.; Gokhan, Z. Some physical and chemical properties of ostrich skins and leathers. Ind. J. Chem. Technol. 2004, 11, 654-658.

31. Dijana, N.; Zlatko, P.; Lilić, S. Evaluation of the ostrich carcass reared and slaughtered in Macedonia. Meat Technol. Mes. 2010, 51, 143-148.

32. Engelbrecht, A. Establishing Genetic and Environmental Parameters for Ostrich (Struthio camelus domesticus) Growth and Slaughter Characteristics. Ph.D. Thesis, Stellenbosch University, Stellenbosch, South Africa, 2013.

33. Naveena, B.; Sen, A.; Muthukumar, M.; Girish, P.; Kumar, Y.P.; Kiran, M. Carcass characteristics, composition, physico-chemical, microbial and sensory quality of emu meat. Br. Poult. Sci. 2013, 54, 329-336. [CrossRef]

34. Akram, M.B.; Khan, M.I.; Khalid, S.; Shoaib, M.; Hassan, S.A. Quality and Sensory Comparison of Ostrich and Goat Meat. SSR Inst. Int. J. Life Sci. 2019, 5, 2168-2175. [CrossRef]

35. Yucel, B.; Taskin, T. Animal Husbandry and Nutrition; IntechOpen: London, UK, 2018; p. 202, ISBN 978-1-78923-420-6.

36. Li, J.; Yang, C.; Peng, H.; Yin, H.; Wang, Y.; Hu, Y.; Yu, C.; Jiang, X.; Du, H.; Li, Q.; et al. Effects of Slaughter Age on Muscle Characteristics and Meat Quality Traits of Da-Heng Meat Type Birds. Animals 2019, 10, 69. [CrossRef] [PubMed]

37. Sharaf, A. Chemical Characteristics of Ostrich Meat in Comparison with Beef and Chicken Meats. Egypt J. Appl. Sci. 2006, 21, 569-580.

38. Sales, J.; Hayes, J. Proximate, amino acid and mineral composition of ostrich meat. Food Chem. 1996, 56, 167-170. [CrossRef]

39. Wideman, N.; O'Bryan, C.; Crandall, P. Factors affecting poultry meat colour and consumer preferences-A review. World's Poult. Sci. J. 2016, 1, 1-14. [CrossRef]

40. Ma, D.; Kim, Y.H.B.; Cooper, B.; Oh, J.-H.; Chun, H.; Choe, J.-H.; Schoonmaker, J.P.; Ajuwon, K.; Min, B. Metabolomics Profiling to Determine the Effect of Postmortem Aging on Color and Lipid Oxidative Stabilities of Different Bovine Muscles. J. Agric. Food Chem. 2017, 65, 6708-6716. [CrossRef]

41. Watanabe, G.; Motoyama, M.; Nakajima, I.; Sasaki, K. Relationship between water-holding capacity and intramuscular fat content in Japanese commercial pork loin. Asian-Australas. J. Anim. Sci. 2018, 31, 914-918. [CrossRef] [PubMed]

42. Horbańczuk, O.K.; Wierzbicka, A. Technological and nutritional properties of ostrich, emu, and rhea meat quality. J. Vet. Res. 2016, 60, 279-286. [CrossRef]

43. Paleari, M.A.; Camisasca, S.; Beretta, G.; Renon, P.; Corsico, P.; Bertolo, G.; Crivelli, G. Ostrich meat: Physico-chemical characteristics and comparison with turkey and bovine meat. Meat Sci. 1998, 48, 205-210. [CrossRef]

44. Romanelli, P.F.; Trabuco, E.; Scriboni, A.B.; Visentainer, J.V.; De Souza, N.E. Chemical composition and fatty acid profile of rhea (Rhea americana) meat. Arch. Latinoam. Nutr. 2008, 58, 201-205.

45. Sales, J.; Navarro, J.; Martella, M.; Lizurume, M.; Manero, A.; Bellis, L.; Garcia, P. Cholesterol content and fatty acid composition of rhea meat. Meat Sci. 1999, 53, 73-75. [CrossRef]

46. Poławska, E.; Lisiak, D.; Jozwik, A.; Pierzchala, M.; Strzalkowska, N.; Pomianowski, J.; Wójcik, A. The effect of the diet supplementation with linseed and rapeseed on the physico-chemical and sensory characteristics of ostrich meat. An. Sci. Pap. Rep. 2012, 30, 65-72.

47. Cooper, R.G.; Horbañczuk, J.O. Anatomical and physiological characteristics of ostrich (Struthio camelus var. domesticus) meat determine its nutritional importance for man. Anim. Sci. J. 2002, 73, 167-173. [CrossRef] 